\title{
Who is thy neighbour?
}

\section{On posthumanism, responsibility and interconnected solidarity}

\author{
DOI: https://doi.org/10.30664/ar.91237
}

(c)(Attribution 4.0 International (CC BY 4.0)

$\mathrm{T}$ his article engages with the question of who our neighbour is, linked to the imperative of love thy neighbour, with the aim of a broadened understanding of who should be seen as a neighbour on an ontological level. First, drawing on posthumanistic theory and its critique of human anthropocentrism, as well as ascribing subjectivity and agency outside the human sphere, it seeks to put it into relation with contemporary theological work. Secondly, it brings together the interconnectedness and interdependency argued by posthumanism and its link with the climate crisis the world faces. Drawing on Hans Jonas's ethics of responsibility and Sallie McFague's kenotic theology, it argues for a responsibility to be taken by humanity through decentralization, as proposed by posthumanism. Finally, it argues for an expanded understanding of the neighbour in the context of all creation, where love should be directed to all beings.

\section{Introduction}

Love thy neighbour. An imperative given in different ways in several religious traditions - but who exactly is this neighbour? Where do we draw the line when it comes to who, or what, constitutes our neighbour? In today's globalised world the question of our neighbour becomes even more pertinent as the world has become increasingly connected, so that classic delimitations are somewhat blurred. As a parallel movement, the political climate of today has become more sceptical, even hostile, towards refugees and immigrants, as many parties are becoming more protective of their own place and borders. In addition to this, the climate crisis shows the interrelatedness of the world in a new way, as it affects all beings on our planet, biotic as well as abiotic. The pertinency of the climate crisis forces us to ask ourselves who our neighbour and other is, as well as how we relate to one another. Humanity's immense impact on the world and its inhabitants has led to a new rationale of climate; this is visible not at least in scholarly discussions of 'the Anthropocene' as a new geological era. This era, it is suggested, shows the impact on our planet that the human race has had, affecting all life on Earth. In this era, the Earth itself is seen as an agent which reacts against the human impact on our planet (Latour 2017: 76; Hamilton 2018: 87-9, 145). This calls for a wider reflection on who should be seen as the other, or, in theological terms, as a neighbour - a subject to whom we relate and who has agency in human life, to whom we should respond and have responsibility towards. Leaning on posthumanistic thought, my aim in this article is to problematise anthropocentrism and address the potential of posthumanistic ideas and comparative theologies, to fruitfully inter- 
act with and counteract such a paradigm. Against this background, I will argue for a widened understanding of who should be considered a neighbour, on an ontological level. This widened understanding includes human and nonhuman beings as well as entities that are part of what we call nature in the definition of neighbours, and I will argue that humanity still possesses a special responsibility for the Earth, not as the only exceptional beings, but rather as one exceptional being amongst many.

In this article I will combine a consideration of the posthumanistic discourse with similar theological and philosophical standpoints to argue for a widened understanding of the imperative love thy neighbour. The posthumanistic discourses will, more precisely, be connected to the kenotic theology of Sallie McFague and Hans Jonas's ethics of responsibility, to create an altered view of how humanity should act in the world and towards other beings.

\section{Questioning anthropocentrism and human dominion}

Posthumanism is a wide and divergent theoretical discourse, with different emphasis given to different arguments depending on which path you choose to follow. The strand that will be the main focus in this article is sometimes designated as critical posthumanism. Critical posthumanisms differ from, for instance, affirmative posthumanisms, which put an emphasis on how human conditions of living have changed to such a degree that we can be said to have gone through a posthumanisation process, due to the impact on human life of technological and cybernetic developments. This, it is argued, has rendered humanity posthuman. ${ }^{1}$ Critical posthumanisms, on the

1 For a more elaborate exposition and comparison between different posthumanistic other hand, seek to destabilise, decentralise and question the understanding of the proper human subject inherited from the humanistic ideal - an ideal that has dominated much of human and Western thought for centuries (Herbrechter 2013: 2-13, 24, 33; Nayar 2013: 2-5). The humanistic ideal - or, as posed by posthumanistic theorists, the humanistic ideology - has resulted in an anthropocentrism that overemphasises rationality, human autonomy, sovereignty and separateness from the rest of the world. Such a separation has allowed for exploitation and abuse of the nonhuman world which has been denied subjectivity and agency in its own right, as only humans are seen as proper subjects. The philosopher Donna Haraway stresses that there has been a dominant idea that it is only humans who affect the world around us; that humans are the only active agents operating in the world (Haraway 2008). Ideas like that have rendered passive and objectified what we call nature as well as animals, and thus made them consumable. ${ }^{2}$

The problem with such an anthropocentrism is not only that it separates humans from the rest of the world, resulting in an unbridgeable dichotomy. According to the cultural analyst Pramod Nayar it has also resulted in a speciesism where species defined as other than human have been seen as consumable. By extension, this has

strands see for example Stefan Herbrechter's Posthumanism (2013).

2 Even though the notion of 'nonhuman animals' has become increasingly popular in order to stress that humans, too, is an animal species, I will here use the term animal for nonhuman biotic life. This because of my own belief that the use of nonhuman for animals falls back into an anthropocentrism due to the fact that we use humans to define animal life. I would rather see a paradigm shift that sees animal life in its own right and own value. 
made humans consumable as well, as some humans have not been considered to fit the definition of 'the human' as perceived from within the humanistic ideology. Thus, they have been conceptualised as other than human (Nayar 2013: 4, 85). Hence, these others have been objectified as uncivilised, irrational and animalistic - beastly even. Haraway expresses a similar view when she writes:

The discursive tie between the colonized, the enslaved, the noncitizen and the animal - all reduced to type, all Others to rational man, and all essential to his bright constitution is at the heart of racism and flourishes, lethally, in the entrails of humanism (Haraway 2008: 18).

The philosopher Rosi Braidotti highlights a similar critique when she writes: ... otherness played a constitutive role, marking off the sexualized other (women), the racialized other (the native) and the naturalized other (animals, the environment or Earth)' (Braidotti 2013: 27). This points to a destructive othering of both other humans, animals and that which we call nature. This othering has made it possible to disregard them, to industrialise and exploit them as they stand outside of the self-reflective definition of a human being, inherited from the humanistic tradition, through the Enlightenment and up until today in close connection to the capitalist paradigm which fostered such exploitation. Not only has such a disregard led to an abuse of nature and an exploitation of natural resources, leading to the climate crisis of today, as well as human and animal life. At the same time, we need to remember that the humanistic tradition also has given us the means to acquire knowledge about the human impact on the climate, for example. Through enabling a new way of critical thinking along scientific and ethical development, the humanistic tradition has given many positive facets to our culture and thinking.

Perhaps many posthumanistic discourses display the tendency, described by the theologian George Pattison, of trying to figure out where in time a wrong turn was made in our thinking. Usually, this tendency also entails the belief that we, in our thinking and understanding, were initially on the right path, but at some point a wrong turn was made (Pattison 1998: 75). In posthumanistic thinking, the humanistic tradition constitutes that wrong turn. It is seen as the root of humanity's divide from the rest of the world, as well as the grounds for economic and structural differences. This is of course somewhat of a simplification, as the lines of history are not as straight as such a view might convey, but for the convenience of the exposition of posthumanistic thinking such implications are connected to the overall humanistic tradition they problematise. Many posthumanistic thinkers do not seek to completely break with the humanistic tradition, as their thinking is simultaneously highly dependent on the scientific, ethical and critical thinking inherited from this era. Rather, many of these thinkers seek to problematise the anthropocentric point of departure in this tradition as well as its inherent view of who or what is excluded or included in the definitions of subjects and agents. As the philosopher Bruno Latour has stated, such a divide is evident in the difference between science and our everyday and political thinking. According to Latour, the sciences - and especially the natural sciences of today take nonhuman actors into account to a larger degree than the rest of society. The sciences include nonhuman actors as part of the population - something that politics 
does not, according to Latour; the sciences take into account the entanglements and rhizomic connections between beings, who are all situated on Earth, which contains more inhabitants and agents than most of us perceive (Latour 2004: 24, 61,72)

To challenge anthropocentrism, or even human exceptionalism is quite challenging in itself, not least for those who stand in biblical-theological traditions. The biblical tradition's impingement on both humanity's exploitation of the Earth and its separateness from the rest of creation has been argued by many. The most striking example is probably the historian Lynn White's classic 'The historical roots of our ecological crisis' (1967) but it has also been addressed by posthumanistic theorists such as Haraway (Svenungsson 2018: 35; Haraway 2008: 245). The concept of the human being as the Imago Dei has been used as a ground for granting humanity dominion over the Earth, as humans have been understood to be God's deputies on Earth, but also somewhat in the role of caretakers of and shepherds for the rest of the creation. Humanity has also often been conceptualised as other than worldly and ontologically different from the rest of creation, having been created differently from everything else. The view of humans as created in God's image could be said to be a double-edged sword: it has been used both as an argument for equal human rights and for regarding humans as responsible caretakers for the rest of creation; but on the other hand it has also been used to exclude those who have been conceptualised as connected to nature. The theologian Wanda Deifelt points out that such a construction in Western thought has resulted in an understanding of women as not fully Imago Dei, both because women have been linked to nature and because the depictions of God as male dominate. This critique is echoed by many feminist theologians (Deifelt 2017: 119-22).

As the theologian Jayne Svenungsson states (2018: 36-7), understandings like the ones proposed by Lynn White have not been unopposed. The biblical legacy is more complex than most of the standard critique allows, and such a critique has also spurred a constructive self-critical reflection within theology. One of the most notable examples in recent years is, of course, Pope Francis's encyclical Laudato Si, as well as the vast and numerous contributions of eco-theologians in later decades. This self-critical reflection has caused criticism of the anthropocentric traditions to arise within theological discussions as well, acknowledging that the biblical traditions, in accordance with many different religious sources, have worked as a basis for an anthropocentric paradigm. Hence, efforts have been made to deconstruct the traditional sources, presenting alternative interpretations of them. Sallie McFague has criticised theological traditions for creating a devastating dualism that has focused on the inner (human) life, rather than an outer life, where salvation (especially in Protestant traditions) has become a matter for the individual human being, rather than for the community or for the oppressed. This has by extension caused an exclusion of large parts of the collective of beings inhabiting the planet (Latour 2004: 83), as well as the Earth, which opens up soteriological questions. A similar critique is addressed by Pope Francis, who argues that humanity separated itself from the rest of creation as rulers and masters. This caused humanity to forget that we, as well as the rest of creation, have emerged from the dust and soil of the Earth (McFague 1993: 28-31; Pope Francis 2015: 3-5, 31). McFague pinpoints this by recapitulating the French philosopher Simone Weil's question of how 
the church can consider itself to be catholic $^{3}$ if it does not see to the whole of creation, but merely humans (McFague 2008: 33). At the same time, Svenungsson highlights that humanity in the biblical texts, despite their anthropocentric tendency, seldom is celebrated in a way that could be connected to the humanistic ideal. Rather, Svenungsson emphasises, the biblical stories describe human vulnerability, destruction and dependency. Svenungsson writes: 'Just as the Hebrew Bible is not a collection of stories about an impassible God, it is not an account of a triumphant humanity that reigns unrestrictedly over creation' (2018: 40). Svenungsson argues that the stories address humanity's partaking in making the world a better place. This could, of course, also be seen as anthropocentric, but at the same time, these stories bear the potential to decentralise the human, as they showcase humans both as imperfect and dependent and as responding to something not fully conceivable and other.

\section{An interconnected and interrelated world}

In contrast to an anthropocentric understanding, posthumanistic theorists emphasise a different ontological understanding. This understanding focuses on interdependency, interrelatedness and becoming-with other life forms, as well as our shared conditions of living and interaction in and with our surrounding world. This interconnectedness and interdependence are a continuation of the decentralising of the human, as humanity is seen as nothing more than one species amongst many. Pramod K. Nayar, for one, argues for a species-cosmopolitism that recognises the symbiotic nature of life on Earth and the common development of species within a shared environment and

3 In the sense of being all-encompassing. socialisation where biotic and abiotic entities interact (Nayar 2013: 113, 123-6). As a new-materialistic movement places the pervading emphasis on living as embodied and material within the shared space that is planet Earth; it is a monism where all is radically joined together and interrelated in an exteriority through embodiment (Wolfe 2009: 90-8). This interconnectedness is not merely biological. Posthumanistic thoughts lean towards evolution theory and biological research to show the connectedness and exchange within the intricate biological system (Nayar 2013: 43-6). Nayar deems that life is always relational through embodied interaction and relationality with the surrounding world and other embodied entities, human and non-human, biotic and abiotic. Subjects develop, according to Nayar, within such an interaction between agents where alterity is needed for the subject to become (ibid. pp. 63-5). As relating and feeling connected through a linkage enables a more significant solidarity to be shown, as we stand in relation with the rest of the world, acted upon in exchanging dynamics of interaction with other than ourselves.

A related view of connectedness to many posthumanistic discourses is presented by Latour, who through his development of actor-network theory influenced many posthumanistic theorists through claiming that anthropocentrism is impossible, as it would need at least one centre, by asking where the boundaries are and who defines them. Rather, Latour argues, we ought to see the inhabitants on our planet as terrestrials who are part of one collective of beings (Latour 2004: 55; Latour 2017: 86). Latour deems that a transition from a subject-object dualism, which dissociates humans and the rest of the world, could be reached through a collective understanding where all inhabitants of the Earth are seen 
as part of a collective of terrestrials. This is so because all inhabitants are dependent on the world's resources and soils for living. If we all are grounded in a common world, Latour asks, do we also see that all are actants in some way, since we affect each other through series of events and actions (Latour 2017: 73-6). Latour also contests that we need to see the Earth as an actor as well, as it is a living organism in itself, the activity of which has only increased in the context our new climate regime. Furthermore, Latour emphasises, if the terrestrial aspect of living is stressed then our dependency on the planet and the whole becomes more evident. Such a dependency where all living beings on Earth are engendered, shows that all beings are a communal collective of inhabitants of Earth. Latour recognises that grasping this idea is in no way an easy task, as it will be filled with conflict and negotiation. It is, however, a necessary task for the sake of our planet and communal home (ibid. pp. 75, 87-95).

Rosi Braidotti has argued, furthermore, that the global market economy within advanced capitalist societies creates immanent egalitarianism, due to the joint exploitation of humans, animals and nature within this system. According to Braidotti (2013: 63), all are subject to capitalist interests and alternate between the role of consumer and product within the global power economy. Sallie McFague, who perhaps could be seen as a posthumanist, has argued that this exploitation rests on the ruling paradigm (especially in Western societies) of individualism that is promoted by consumerism and capitalism, a paradigm that has allowed others to be exploited as long as individuals' own desires and self-fulfilment are satisfied (McFague 1993: 3-7; McFague 2013: 141). Donna Haraway has instead advocated an autre-mondialisation, a sort of globalisation beyond capitalist interest, and she emphasises a more solidary, peaceful and connected world beyond capitalist interests, based on global movement and connection between different beings (Haraway 2008: 3, 19). Autremondalisation has a similitude to what Latour has called globalisation-plus, where the main focus is letting the plurality and multiplicity of voices on the globe be heard. This type of globalisation emphasises the inclusion of several views, phenomenons and understandings, as well more organisms to some degree. Latour contrasts this with globalisation-minus that rather seeks an overall and encompassing standard and likeness which should be applied to all (Latour 2017: 12-13).

\section{Theological arguments \\ for an interconnected world}

The interconnectedness, interdependency and relational aspects of the world have been put forward from a theological point of view as well. This theological view draws on both an evolutionary understanding, where everything originates and evolves from a common source, as well as classical theological notions of the world and everything in it as created. Arguments have been made for a radical unity within the world. Pope Francis deems that if we feel attached and united with the whole as all are created, we will feel solidarity with all in creation and therefore care for its wellbeing. This would enable us, according to Pope Francis (2015: 11, 25-9), to bring the whole of humanity together to work for a sustainable and ecological development. Such a development will heal the Earth, both relationally and environmentally, as both these aspects have been damaged according to Pope Francis. McFague seeks a common creation story, founded upon the big bang and evolution, which according to her is taking all life into account and 
not only humanity which has been the case with most creation myths. According to McFague, a common story and shared origin of beginning shows the radical interdependence, relationality and entwinedness that characterises the big bang, as well as the principles of radical diversity and individuality due to evolutionary development. Additionally, such a view indicates that the main concern should be loyalty and solidarity towards our planet and all life that inhabits it - instead of ethnicity, nation or other belonging that leads to a degrading separateness (McFague 1993: 27-9, 38). Another emphasis to mark the connection of life and its belonging to Earth has been through God's life-giving spirit, which sustains life as well as dwelling on Earth. The theologian Cynthia Moe-Lobeda explores how the spirit in the biblical texts is something universal and communal and which permeates everything, thus connecting it to all things (Moe-Lobeda 2017: 269-72). Despite these different emphases in conceptions of the world's interrelation and interconnectedness, as well as arguments of interdependence and critiques of anthropocentrism, there is still quite a vindication for some sort of human exceptionalism and intrinsic value from many theologians. For example, both Pope Francis and the theologian Daniel P. Scheid criticise an anthropocentric understanding, but still urge for human exceptionalism due to its intrinsic value, trying to avoid anthropocentrism in favour of a theocentric understanding. Despite this effort, I would argue that ascribing a higher value to humanity in the end runs the risk of falling into an anthropocentrism where humans remain the measurement of all. In contrast to this value-based exceptionalism I believe it to be possible to ascribe some sort of exceptionalism to humans, as with every other species. The cultural critic Carey Wolfe points out that other species have capabilities and abilities that humans are less good at, or do not possess (Wolfe 2009: 37-41). As McFague has stressed, we need to recognise both the unity and individuality, solidarity and difference, as multiplicity is needed for continued common life. Therefore, it is possible to ascribe some sort of exceptionalism for all species in their own uniqueness, without denying the unity between beings. This view of exceptionalism will become relevant later for an understanding of the ethical responsibility addressed below.

\section{Climate change and a common home}

Thus far we have seen questions raised concerning who and what we address as subjects and agents, with the intention of invoking a more porous ontological understanding of subjectivity and agency. The conference that laid the ground for this article focused on the themes of hospitality and solidarity. ${ }^{4}$ With the help of posthumanistic critique, this raises questions about who and what we should be hospitable and in solidarity with, as well as who should be shown neighbourly love. I argue, and I am not alone in this, that those denied subjectivity and agency have also been denied displays of hospitality, solidarity and neighbourly love. The interconnectedness of life on Earth, the shared space and conditions of living together in interrelation with different beings on Earth, becomes increasingly evident in relation to the climate and ecological crisis, as it affects our shared space. If all beings are interconnected or, in Latour's terms, form a collec-

4 'Feminism and Hospitality: Religious and Critical Perspectives in dialogue with a Secular Age', arranged by the Nordic Summer University (NSU) Turku, Finland in March 2020. 
tive, questions of hospitality, solidarity and neighbourly love need to be asked again. This is because of the widened spectrum of who we share our planet with and to whom we need to show care.

If we should for a moment dwell on the question of hospitality we could start with this thought: the Earth is the host of all life forms and we humans, as its guests, have overstepped the boundaries of the hospitality shown to us. I do not believe this statement to be accurate, as the Earth is the home and not the host of all living and non-living within the ecological whole. To say that humans are the guests would be to enhance the conceptualisation of humans as 'other than worldly', which leads us back to the question of the separation between humans and the rest of the earthly world. Neither can it be said that humans are the hosts, or perhaps shepherds, of animals or other beings on Earth, as it would enhance the dichotomy which separates humanity from the rest. What I deem, is that this could be a helpful thought experiment to make us think about how we act towards the Earth and its inhabitants as a whole.

What could be said though, is that more and more places on Earth become inhospitable to life as climate change and natural catastrophes make fewer places habitable. This will result in vast numbers of climate refugees in the coming years according to a report from the Environmental Justice Foundation (2017) - perhaps the biggest ever seen. This calls for a recognition that those who are most affected by this are people in poor and developing countries, areas that have been subject to exploitation by the north-western part of the globe, which has been legitimated by capitalist and humanist ideologies. We have seen several examples, in the rhetorical and political climate, of refugees being all too often dehumanised, called animals and denied their own subjectivity. Alongside these peoples, animals are also losing their habitats due to human destruction. Pope Francis says in his encyclical that the Earth and many animals could be added to the category of poor and oppressed beings as a consequence of this situation (Pope Francis 2015: 19-20). There is no doubt that the responsibility for the ecological and climate crisis we face is to be applied highly asymmetrically; a small part of the world's population has done far more damage than those who are affected the most. It can be said that this calls for a need to show hospitality to these refugees who are losing their homes, but at the same time hospitality is time bound and impermanent. No one wants a guest who overstays their welcome. ${ }^{5}$ It becomes then difficult to think of refugees, who might have lost their home permanently, as guests to whom we should be hospitable ${ }^{6}$, as it would oblige us to conceive of a permanent guest. A similar problem concerns animal life, if we were to address them as guests. Does it not become either an act of anthropomorphism, which Nayar argues (2013: 93) takes us back into anthropocentrism, or otherwise contradictory, as the Earth is as much their home and space of living as it is humanity's? I believe that posthumanistic discourse can be helpful in its emphasis on the interconnectedness of both biotic and abiotic beings, with common conditions for all beings in the shared space that is the Earth. The notion of a radical interrelation, where something happening across the globe effects directly

5 I thank Anne Katrine Gudme for this pertinent remark in her presentation at the NSU Winter Symposium in Turku, Finland, 4-8 March 2020.

6 My case here is not to argue against an act of hospitality, which I do not see as something bad; rather I am focussing on its ontological understanding. 
or indirectly the whole, becomes distinctively evident in questions of emissions and catastrophes or related events. We need a new understanding of our shared home Earth in handling the climate crisis and its consequences. If we do so, talking about guests and hosts on a global scale becomes impossible, especially if we see the whole world as a collective as argued by Latour. Perhaps there is a need to talk about neighbours, which indicates an affinity and calls for solidarity.

At the same time, there is a need for responsibility, or in Haraway's words, an ability to respond to the climate challenges we face. On whom the ethical responsibility falls has been somewhat indistinct in many posthumanistic theories. In several cases it has fallen into a somewhat paternalistic understanding, where humanity still has the main responsibility as a species. This is reinforced by humanity's possession of power over other beings, expressed by Braidotti (2013: 100) amongst others. The philosopher Rosalyn Diprose as well as Jayne Svenungsson have both expressed concern over the consequences of an indistinct ethical responsibility which would get humans off 'the ethical hook' (Diprose 2009: 9; Svenungsson 2018: 45). This problem becomes evident when it comes to the climate crisis, which is largely to be blamed on human action and calls for responsibility to be taken for the damage caused to the climate and planet as well as its inhabitants. I argue that a distinction needs to be made between the ontological and ethical understandings of this matter. These strands lead into conversation with Hans Jonas and his ethics of responsibility, as well as the theological work of McFague who, as mentioned earlier, is perhaps the theologian standing closest to some sort of posthumanistic discourse in her thoughts of kenotic living in order to give space for others.

\section{Responsibility and giving space to others}

The philosopher Hans Jonas devoted much of his philosophical work to counteract the anthropocentrism and beliefs of human autonomy he found to be prevalent. Jonas ascribed subjectivity to the non-human world as well as to life and being itself: '... the most elementary stimulation of organic irritability as such, in which somehow already otherness, world, and object are germinally "experienced," that is, made subjective, and responded to' (Jonas 2000: 2-3). This subjectivity, ascribed in all living things, makes Jonas an interesting interlocutor with the posthumanistic discourses discussed above, as he shares a wide and inclusive definition of subjectivity and agency.

Despite Jonas's wide definition of subjectivity and agency, the principle of an ethical responsibility that falls to humanity is very clear. Jonas states that this responsibility has nothing to do with an intrinsically higher human value; rather it is a burden that is consequent upon evolutionary development, as every evolutionary step brings into being the utilisation of a higher degree of functions and abstractions which entails the responsibility (2000: 167$73,283)$. The acquisition of this burden is not only due to an evolutionary process though. Humanity's development and obtainment of artificial technology has, according to Jonas, led to an even bigger requirement of responsibility, as it has disrupted the balance that Jonas found to be the case before this development. Jonas argues that this technology has allowed humanity to accumulate a higher degree of power which not only affects the climate and other species and beings, but also threatens the continued existence of life on our planet and harms the whole biosphere - something that demands responsibility to be taken as humanity's position of power 
has the potential to cause great harm (Jonas 1994: 59, 68). This human destructiveness has caused ecological deterioration, climate crisis and, according to some, the world is approaching a sixth mass extinction of life forms on our planet (Briggs 2017).

McFague, too, addresses the asymmetrical and unbalanced power relations between beings. To grapple with such an asymmetry and inequality McFague makes use of the classical theological notions of sin and fall. The human fall is, according to her, the unwillingness to stay in our place; confining ourselves to the space given to us humans as well as accepting our limitations. Sin is thus signified by denying others - humans and the rest of creation the right to their space and needs. McFague highlights space as the connection between ecology and justice, where humanity and especially some sections of the human species, have taken and misused others' space. McFague deems that the abundance of some parts of the world we have lived and still live in, are killing other humans, other life forms and our Earth through a destructive lifestyle. This space has been claimed selfishly by the privileged of the world, something that according to McFague has led to exploitation of the rest. McFague argues that this is closely connected to the climate crisis, as those most affected by the changing climate and ecological deterioration are those who have been denied their space. This includes humans and nonhumans who have been oppressed historically, are being so currently, and who live in areas that suffer more from the changing climate (McFague 1993: 112-14; McFague 2008: 36; McFague 2013: 129-31). It is a fact that makes their space even smaller in these areas, which calls for a need to give space to those who have lost it.

Jonas argues that the responsibility needs to be grounded in an ontological understanding as it affects the whole world. Jonas uses the deductive statement that being is more valuable than non-being. As being on an ontological level is preferable in relation to non-being, this applies to all beings, humans as well as non-human lives (Jonas 1994: 83-92). Because of the ontological level of the ethics the responsibility is based upon the preservation of life and continued existence for each species focusing less on individual cases, as the life of species encompasses living and dying. What is central for Jonas is that no actions can be allowed to be taken that threaten the existence or continued existence of any species $^{7}$, as a species' existence has a higher value than economic and technological development, or individual life even (ibid. pp. 168, 210-14).

McFague on the other hand places a greater emphasis on accountability than Jonas - an accountability which falls on those who have used the most resources and lived in the greatest abundance. To counteract both the paradigm of individualism, exploitation and separateness as well as the asymmetrical power relations on the planet, McFague proposes a kenotic lifestyle. This kenotic or self-emptying lifestyle should not be understood as a total annihilation of the self, but rather giving up some of one's abundance in solidarity with others: to allow them their space and cater for their needs. Such a space-giving should be understood in a wide sense, not using more than is needed to fulfil one's basic needs. Or perhaps in connection to the question of climate refugees stated above, to give space to those who have lost their space due one's own abundant living (McFague 2013: 88-96).

7 The term pecies here should be understood in its widest sense, including plant life etc. 
Although such a responsibility - for the prevailing life on Earth, as well as for giving space to others - falls on all of humanity as a collective, it falls on some humans more than others. This is of course due to the prevailing power structures in the world. Jonas states that power entails an obligation to care for the existence and flourishing of others (human or not) on the basis of the dominant position of the one that possesses power (Jonas 1994: 147-50). Such an emphasis could be problematic as it might be seen as ratifying current power relations, affirming one's power over the other. Rosalyn Diprose addresses this problem of power relations when she stresses that an ethics for the complex and concatenated world in which we live must oppose the normalisation of ruling over others. Ethics, she argues, should take account of the plurality and multiplicity of identities that exist, where the uniqueness of each individual, human or nonhuman, is respected and enabled to keep its own identity (Diprose 2009: 11-14). Jonas touches on the same topic when he stresses that the powerbearing party ought to enable the other to develop and prosper as is best for the other, in ways undefined by the dominant party. In its dependency the other has in its otherness to rely on the more powerful party to take responsibility for this other's existence (Jonas 1994: 157, 170). This is not a question of denying the asymmetry of power that exists in relations. Latour has expressed it as exercising power as power, recognising that there is power and that some occupy it more than others (Latour 2004: 222). Jonas bears some resemblance to the Catholic social teaching of the preferential option for the poor. This teaching is based upon understanding that the utmost consideration should be shown to those who need it the most, with the purpose to exalt them by enabling their equal participation and capability. This is based on the belief that it is better to enable someone than to merely show consideration for the person, so that all can partake as equals in the communal space (Scheid 2016: 82-5). It is therefore not so much a case of validating current power structures; but rather recognising that there is an asymmetric balance in power, which in continuation enables a change of these structures.

Here McFague's argument for a kenotic lifestyle comes in handy. Kenotic life, according to McFague, consists in affirming that something or someone other is as real as oneself and that this other has its own needs, where all are interdependent on each other. Thus, kenotic life is an act of reciprocity, affirmation and solidarity, where we pay attention to others. The social psychologist Johan Asplund has stated that one can never fully see oneself through one's own eyes, but the I can be seen by the other and thus becomes affirmed. For such an affirmation to become possible there is a need for space to be made for the other, so that the other has the possibility to see (McFague 2013: 88-96, 143-9; Asplund 1987: 20, 30). Such an affirmative life consists therefore of sharing space; a common space that all should have access to, as this space is the common home of our planet. McFague states that kenotic life consists of a limitless and unqualified empathy and love for the other, regardless of whether this other is known or unknown. Both Jonas and McFague draw inspiration for a kenotic life from the Kabbalistic tradition, where God emptied and drew back itself to create the world, and made space for life in creation. All created things should then act accordingly, as we share a common planet and resources (McFague 2013: 11618; Jonas 1996: 136-42). It is important to consider that the kenotic life McFague advocates first and foremost should be 
applied by those who have taken space and exploited others - those who live in abundance by global standards and therefore do the greatest harm to the whole within our common earthly system. In a later stage this could be said to apply to everyone, when the disequilibrium in assets and standards has been equalised.

At the same time we need to ask ourselves whether this lands in an anthropocentrism, as the focus once again falls back upon the human as the responsibility-bearing subject, to use Jonas's term. It could of course be said that putting the responsibility solely on humans as the ones who should respond to the situation, we fall back into an anthropocentrism in centralising the human. I argue that this does not need to be the case. If the human is decentralised as it is in Jonas's ontological ethics and posthumanistic thoughts, the main focus is not human exceptionalism on the basis of possessing a higher value, but rather an obligation to care for others. As stated above, all species could be understood to have some sort of exceptional position, and humanity's exceptionalism could be the ability to take this responsibility, among other characteristics. Both due to our dominant position from our accumulated power, but also because of our ability to reflect on the threat inherent in the situation and act upon these reflections to make a change. Diprose points out that as humans, we always have to start from a human position (Diprose 2009: 13-14). Diprose makes a crucial point, in relation to some posthumanistic thinking, as it would be paternalistic, if not impossible, for us to dictate an ethics for animals to abide by. As humans, we have to start from our own perspective and what we can do, but we also have to recognise, as Latour argues, that it is human scientists that work as spokespersons for the nonhuman world through scientific research. It is humans who are talking; therefore we must remember that we do not know the whole picture (Latour 2004: 71). I return to Jonas and his idea that the continued being of a species is better than non-being. It would in practice result in saving the endangered animal to save the whole of the species, instead of a human if the choice had to be made. I would not call this anthropocentric; rather I would contest that it is a recognition of the asymmetrical relations and conditions that pertain between species as well as humans.

\section{Love thy neighbour - all neighbours}

In conclusion, I would like to turn to the example of the classical ethical imperative of love thy neighbour as it is specifically formulated in the Judeo-Christian traditions. With a narrow definition of both subjectivity and agency, the neighbour has often been defined as belonging to one's immediate vicinity, or as a member of one's own group. St Augustine argued that all of humankind should be considered a neighbour and a subject for neighbourly love, due to their createdness and earthly birth. Such love includes showing compassion, mercy, hospitality and care for the neighbour (Stewart-Kroeker 2017: 206, 212). An uncapacious definition of who one's neighbour is has denied this love to some humans as well as the rest of creation, as argued above - which has resulted in a disregard for their needs and their space, to use McFague's argumentation. If the definition is widened, as showed by Jonas, posthumanistic thoughts and some theological viewpoints which have all argued for an interconnectedness, interrelatedness and shared home/space, with a widened understanding of subjectivity and agency, perhaps it is possible to widen the understanding of the neighbour as well. If we consider Augustine's definition, that all humans are created and originated on the Earth and 
should therefore be seen as one's neighbours, then the same can be said about nonhuman beings as well, this being so because of their aforesaid createdness and generation from the Earth. If the conditions for all humans to be seen as neighbours is based on them being earthbound and created, all of creation should be included in this neighbourly love and acts of compassion and concern.

As we live together and thus stand in relation to others in our common home planet Earth - it could be said that on an ontological level all who exist within this connected world are neighbours. If all are neighbours, on an ontological and global level it becomes impossible to speak of guests and hosts. Rather, we should be understood as parts of a common collective. Love and care for the neighbour should then be directed to all. If the other, human or not, is our ontological neighbour, then there is an imperative to love it and understand that the Earth is our common home, in which the other cannot be dismissed. McFague has expressed similar views, as she states that the Earth's intricate systems and its inhabitants are equally important for keeping life viable. If life is to be loved, McFague urges that we ought to widen the circle of whom to love, so that it includes all that is keeping it and us alive (McFague 2013: 130). What our relation to the neighbour could be said to be, if we consider their needs, continued living and dependency on others, is a response and affirmation to someone or something else. This brings us back to the notion of Imago Dei, as there have been several alternative definitions proposed other than that of the human species's dominion over creation. For example, Jonas has interpreted the Imago Dei as humans standing in relation and intercommunication with others, in whose images we reflect the ability to say
I, as our selves are only an image and not fully in our possession. Another alternative is that we see the Imago Dei to be a call to love and see the goodness of everything in creation, in accordance with how God perceives the world in the narrative of creation in Genesis (Jonas 2000: 186; DeaneDrummond 1997: 160-5). These views stand in accordance with McFague's argument that a basis in a theological understanding of life where the self is not complete in itself; it is responsive to an external call, much as Asplund deems above. This call comes from an other, on whom we depend. This other can be both that which is called God in its primordial sense, or an other who is one's neighbour on Earth and thus other than human as well (McFague 2013: 153). As with that which is called God, something we do not fully understand and conceive; the other and especially nonhuman life forms stand in close analogy, as we do not fully conceive that other. God has not been disregarded throughout history, why then should other life forms be?

If the Imago Dei consists of responding to and loving others, as well as the neighbourly love consisting of care and compassion towards other created beings, then we have to include all of creation in this love. Such love could be understood as reaching and moving out of oneself, towards the other, the neighbour. In such an act of love, the care for the other's life should be taken into account, where we in solidarity preserve the life on Earth, in accordance with Jonas's ethics. In such an understanding a potential is inherited in the theological tradition, on the topic of broadening the understanding of who our neighbour is, when we tackle the separateness between humans and the rest of the world, to see ourselves, in Latour's way, as part of a bigger collective. Therefore, I do believe an expanded and porous conceptualisation 
of who our neighbour is could be helpful, as it amplifies the interdependency and interrelation of all beings on Earth. It also brings a responsibility to care and respect these others - our neighbours - in solidarity due to our attachment and interconnectedness within the collective of earthly beings, based on the imperative of love thy neighbour. Such a responsibility could be inspired by both Jonas in his argument for protecting and caring for life as such. Also, McFague's notion of giving space to life becomes evident in a neighbourly understanding, as we live together. Humanity is without a doubt the biggest cause of today's climate crisis, and other threats to life on our common planet, but at the same time humanity possesses the capability to make an immense change. This duality calls for a responsibility to be taken for the continued existence of the world, as a whole, where all neighbours are respected, shown solidarity and love within the common home of planet Earth.

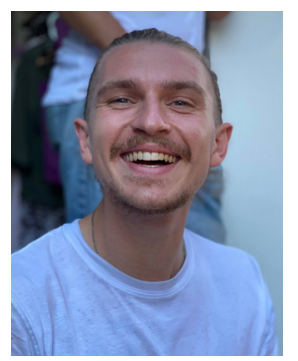

Jakob Signäs is a MA student in Studies in Faith and Worldview at Lund University, Sweden. He holds a BA degree in theology from Lund and has previously worked on the question of human autonomy in relationship to God and salvation in Søren Kierkegaard's thinking. His MA thesis investigates the challenges posed by critical posthumanist discourse to theology, with the aim of proposing a critical interaction between posthumanist thought and contemporary theology. Further areas of interest are eco-theology, the history of ideas and political theology.

\section{Literature}

Asplund, Johan. 1987. Om hälsningsceremonier, mikromakt och asocial pratsamhet (Göteborg: Bokförlaget Korpen).

Braidotti, Rosi. 2013. The Posthuman (Cambridge: Polity Press).

Briggs, John C. 2017. 'Emergence of a sixth mass extinction?' Biological Journal of the Linnean Society, 122: 243-8.

Deane-Drummond, Celia. 1997. Ecology in Jürgen Moltmann's Theology, $\mathrm{PhD}$ dissertation (New York: Edwin Mellen Press).

Deifelt, Wanda. 2017. 'And $\mathrm{G}^{\star} \mathrm{d}$ saw that it was good: Imago Dei and its challenges to climate justice, in Planetary Solidarity: Global Women's Voices on Christian Doctrine and Climate Justice, eds. Grace Ji-Sun Kim and Hilda P. Koster (Minneapolis, MN: Fortress Press), 119-32.

Diprose, Rosalyn. 2009. 'Toward an etichopolitics of the posthuman: Foucault and Merleau-Ponty', Parrhesia, 8: 7-19.

Environmental Justice Foundation, 2017. Beyond Borders. Our Changing Climate: Its Role in Conflict and Displacement (Oxford: Seacourt).

Hamilton, Clive. 2018. Den trotsiga jorden: människans öde i Antropocen [original title: The Defiant Earth: The Faith of Humans in the Anthropocene, 2017], trans. Joel Nordqvist (Göteborg: Daidalos).

Haraway, Donna. 2008. When Species Meet (Minneapolis: University of Minnesota Press).

Herbrechter, Stefan. 2013. Posthumanism: A Critical Analysis (London: Bloomsbury Publishing).

Jonas, Hans. 1994. Ansvarets princip. Utkast till en etik för den teknologiska civilisationen [original title: Der Prinzip Verantvortung, 1979], trans. Per Carleheden (Göteborg: Daidalos).

---1996. Mortality and Morality: A Search for the Good after Auschwitz (Evanston, IL: Northwestern University Press).

- - 2000. The Phenomenon of Life: Toward a Philosophical Biology (Evanston, IL: Northwestern University Press).

Latour, Bruno. 2004. Politics of Nature: How to Bring Science into Democracy, trans. Catherine Porter (Cambridge, MA: Harvard University Press). 
- 2017. Down to Earth: Politics in the New Climate Regime, trans. Catherine Porter (Cambridge: Polity Press).

McFague, Sallie. 1993. The Body of God: An Ecological Theology (London: SCM Press).

- -2008. A New Climate for Theology: God, the World and Global Warming (Minneapolis, $\mathrm{MN}$ : Augsburg Fortress).

- -2013. Blessed are the Consumers: Climate Change and the Practice of Restraint (Minneapolis, MN: Fortress Press).

Moe-Lobeda, Cynthia. 2017. 'The spirit as moral-spiritual power for earth-honouring, justice-seeking ways of shaping our life in common', in Planetary Solidarity: Global Women's Voices on Christian Doctrine and Climate Justice, eds. Grace Ji-Sun Kim and Hilda P. Koster (Minneapolis, MN: Fortress Press), 249-75.

Nayar, Pramod K. 2013. Posthumanism (London: Polity Press).

Pattison, George. 1998. The End of Theology: And the Task of Thinking About God (London: SCM Press).

Pope Francis. 2015. Laudato Si: On Care for Our Common Home (Vatican City).

Scheid, Daniel P. 2016. The Cosmic Common God: Religious Grounds for Ecological Ethics (Oxford University Press).

Stewart-Kroeker, Sarah. 2017. Pilgrimage as Moral and Aesthetic Formation in Augustine's Thought (Oxford University Press).

Svenungsson, Jayne. 2018. 'Interdependence and the biblical legacy of anthropocentrism on human destructiveness and human responsibility', Eco-Eticha, (7): 35-47.

White, Lynn. 1967. 'The historical roots of our ecological crisis', Science, 155(3767): 12037, doi: $<10.1126 /$ science.155.3767.1203 $>$.

Wolfe, Carey. 2009. What is Posthumanism? (Minneapolis: University of Minnesota Press). 